\title{
PENGARUH KOMUNIKASI HORISONTAL, KOMUNIKASI VERTIKAL DAN KOMUNIKASI DIAGONAL TERHADAP SEMANGAT KERJA KARYAWAN DI PERUSAHAAN JAMU PARANG HUSADA KEDIRI
}

\author{
Erna Hidajati Koesoemaningroem \\ Dosen Universitas Kadiri - ernakoesoema@gmail.com
}

\begin{abstract}
Abstrak
Produsen jamu di Kediri berkembang pesat mendorong industri jamu mampu bersaing untuk merebut minat masyarakat.Perusahaan Jamu Parang HusadaKediri dalam persaingan tersebut menghadapi masalah yaitu masih bernuansa tradisionalisme, letak perusahaan yang jauh dari keramaian kota, yaitu di Dusun Purut Desa Parang Kecamatan Banyakan Kabupaten Kediri.Tujuan dari penelitian ini yaitu untuk mengetahui sampai seberapa besar pengaruh dari komunikasi tersebut secara bersama - sama terhadap semangat kerja karyawan dan untuk mengetahui sampai seberapa besar saluran komunikasi yang paling dominan berpengaruh, diantara ke tiga komunikasi tterhadap semangat kerja karyawan dan untuk mengetahui sampai seberapa besar saluran komunikasi yang paling dominan berpengaruh, diantara ke tiga komunikasi tersebut terhadap semangat kerja karyawan. Dari hasil pengujian dengan menggunakanstatistik program SPSS diketahui, bahwa variabel komunikasi vertical, komunikasi horisontal dan komunikasi diagonal secara simultan mempunyai hubungan terhadap semangat kerja karyawan. Hasil pengujian dengan regresi berganda diketahui persamaan regresi hubungan antara variabel adalah $\mathrm{Y}=6,860+0,263 \mathrm{X}_{1}+0,242$ $\mathrm{X}_{2}$

$+0,358 X_{3}$. Untuk komunikasi yang dominan dapat diketahui bahwa variabel

$\mathrm{X}_{3}$ (variabel komunikasi diagonal) mempunyai pengaruh yang paling dominan dibandingkan variabel lainnya.
\end{abstract}

Kata kunci : Komunikasi horisontal, komunikasi vertikal dan komunikasi diagonal,

\section{PENDAHULUAN}

Dalam sebuah lembaga ataupun perusahaan, tugas seorang manajer pada hakekatnya adalah bekerja dengan dan melalui orang lain (atasan, bawahan, atau rekan sejawat). Dalam menjalankan tugasnya tersebut seringkali masalah-masalah yang dihadapi oleh seorang

Pimpinan/manajer adalah masalah-masalah yang berhubungan dengan " Mengatur Orang ".suatu misal atasan yang kurang komunikatif, bawahan yang kurang termotivasi, konflik antar karyawan/departemen ataupun masalah serupa lainnya. Maka untuk mengatasi masalah tersebut seorang pimpinan/manajer harus memiliki " People Skill “ yang baik.Artinya bahwa seorang pimpinan atau manajer haruslah orang yang sudah berpengalaman dalam mengelola perusahaan, dimana beliau pernah merasakan saat jadi bawahan hingga sebagai orang manajer.

Organisasi seperti halnya manusia dapat diidentifikasi dari perilakunya. Perilaku Tersebut dapat positif ataupun negatif. Banyak definisi tentang perilaku organisasi. "Perilaku 
Organisasi " adalah sebagai penelaahan perilaku, sikap, dan prestasi manusia di dalam suatu kerangka organisasi, penggunaan teori, metode dan prinsip-prinsip dari berbagai disiplin ilmu seperti psikologi, sosiologi dan antropologi budaya untuk mempelajari persepsi nilainilai, kapasitas belajar dan tindakan-tindakan individu ketika bekerja didalam kelompok dan didalam organisasi secara keseluruhan, penganalisisan dampak lingkungan luar atas organisasi dan sumber daya manusia, misi, tujuan, dan strateginya

SebuahOrganisasiterdiridariberbagaikegiatan,dimanakegiatanyangsatumempunyai hubungan dengan kegiatan yang lain, akhirnya merupakan suatu keseluruhan kegiatan yang utuh untuk tujuan yang telah ditentukan. Berbagai tindakan dan cara yang dilakukan oleh pimpinan organisasi. Di dalam suatu organisasi, banyak faktor yang mempengaruhi dalam pencapaian tujuan, tetapi faktor yang paling penting adalah manusianya.

Jelas dikatakan bahwa manusia adalah merupakan unsur yang paling $\bar{p}$ enting di dalam mencapai tujuan organisasi. Oleh sebab itu pimpinan organisasi harus selalu memperhatikan semangat kerja dari para karyawanya, karena dengan semangat kerja yang dimiliki oleh para karyawan, maka tujuan organisasi akan lebih mudah dicapai.

Adanya komunikasi ke bawah yang dilakukan oleh pimpinan secara baik, maka sebagian kebutuhan sekunder atau kebutuhan sosial psikologis akan dapat terpenuhi, maka para karyawan merasa puas dalam bekerja dan akan menimbulkan kinerja yang baik.

Dalam melakukan komunikasi, perusahaan harus mempergunakan strategi yang benar, agar apa yang dilakukan itu dapat menghasilkan yang lebih baik secara optimal. Beberapa faktor yang diperlukan untuk strategi antara lain seperti tujuan, cara kerja, teknologi, masyarakat dan pelanggan, budaya SDM dan sumber daya lainnya. Dengan mengenal faktorfaktor tersebut akan dapat disusun suatu langkah bagaimana membuka peluang keberhasilan melalui komunikasi untuk merubah sikap dan perilaku baru yang kondusif terhadap tantangan yang dihadapinya.

Perubahan sikap dan perilaku tersebut dapat menjadi kenyataan bilamana SDM telah mendapat nilai-nilai baru, kemudian mereka mempunyai alat atau perangkat untuk melaksanakannya, sehingga nilai-nilai tadi menjadi kenyataan yang lebih baik dan terus dipelihara dan dikembangkan. Individu-individu dalam organisasi akan efektif manakala terjadi hubungan dan komunikasi yang baik dan harmonis dalam organisasi atau perusahaan, dimana komunikasi tersebut akan menambah rasa percaya diri, karena merasa mendapat perhatian dari pimpinan atau teman sekerjanya. Pada situasi "emotional condition" akan menguatkan dirinya untuk lebih giat dan bersemangat menjalankan tugas-tugas yang dibebankan kepada mereka.

Perusahaan Jamu Parang Husada Kediri, merupakan salah satu perusahaan yang dalam proses perkembanganya banyak melibatkan semua unsur manajeman dan fungsifungsi organisasi. Perusahaan yang budaya karyawannya masih sarat dengan nuansa tradisionalisme ini membutuhkan perhatian tersendiri dari pimpinan perusahaan, komunikasi harmonis antara pimpinan perusahaan dan karyawan merupakan modal kuat keberlangsungan perusahaan. Dari gambaran singkat perusahaan peneliti mendapatkan permasalahan yang dihadapi perusahaan adalah :

a. Budaya organisasi yang masih bernuansa tradisionalisme, karena letak perusahaan yang jauh dari keramaian kota. 
b. Hubungan yang terjadi di perusahaan ini tidak ada sekat pemisah antara pimpinan dan bawahan, Komunikasi berlangsung dengan apa adanya.

Kemudianapakah dengan kondisi internal perusahaan ini , Komunikasi yang terjadi akan efektif dengan hasil output yang baik bagi perusahaan dan berpengaruh kuat terhadap semangat kerja karyawan?

Ketangguhan suatu organisasi baik itu pemerintah, bisnis maupun masyarakat dapat ditelusuri yang bermuara pada perusahaan yang mampu memberikan komunikasi yang benar dan menarik dalam keikutsertaan karyawan dalam bekerja. Semangat kerja akan timbul apabila suatu organisasi dimana ia bekerja dapat memenuhi kebutuhan hidupnya. Sedang kebutuhan hidup manusia dibagi menjadi dua: "Kebutuhan manusia ada dua jenis, pertama kebutuhan primer atau kebutuhan phisikologis yang pokok, kedua kebutuhan sekunder atau kebutuhan sosial psikologis".

Masih banyak pimpinan organisasi yang kurang memperhatikan semangat kerja para karyawanya. Hal ini dapat dilihat dari adanya karyawan yang sering tidak masuk kerja tanpa ijin, tidak adanya kesetiaan dan kebanggaan terhadap organisasinya, dan sebagainya. Peneliti memilih perusahaan Jamu Parang Husada Kediri sebagai tempat penelitian, karena perusahaan tersebut mengutamakan komunikasi yang dapat meningkatkan semangat kerja karyawan. Produksi perusahaan lancar dan manajemen perusahaan tetap stabil hingga saat ini, walaupun ada beberapa produk merk jamu pesaing yang mendapat peringatan dari Badan Pengawas Obat Dan Makanan ( POM ), produkproduk jamu dari perusahaan ini berhasil lolos dan tetap dipercaya masyarakat.

Dengan latar belakang serta penjelasan tersebut di atasmaka penulis mengambil judul penelitian skripsi saya, adalah : "Pengaruh Komunikasihorizontal, komunikasi vertikal, dan komunikasi diagonal Terhadap Semangat Kerja Karyawan di Perusahaan Jamu Parang Husada Kediri““

\section{Kerangka berfikir}

Secara sistematika kerangka pemikiran dapat digambarkan sebagai berikut : Gambar 1

Kerangka berfikir

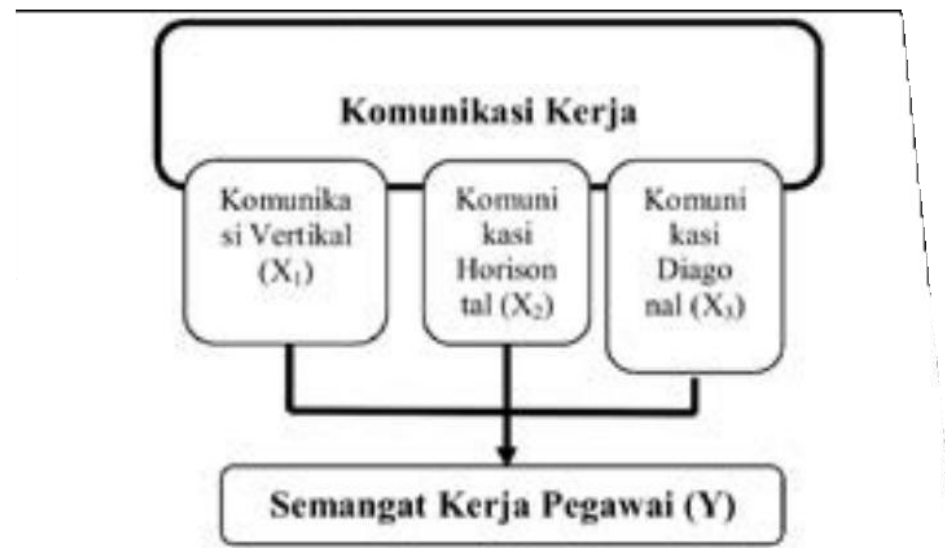

Keterangan:

Variabel independen (variabel bebas), yaitu variabel yang diagonal terhadap semangat kerja Karyawan (Y). 
Dari kerangka pemikiran di atas dapat dijelaskan bahwa komunikasi kerja (X) yang terdiri dari komunikasi vertikal (X ), komunikasi horisontal (X ) dan komunikasi diagonal $\left(\mathrm{X}_{3}\right)$ mempunyai pengaruh terhadap semangat kerja karyawan $(\mathrm{Y})$ pada di Perusahaan Jamu Parang Husada Kediri.

\section{Hipotesis}

Hipotesa adalah sebuah kesimpulan tetapi belum final, dan masih harus dibuktikan kebenarannya. Kemungkinan menjadi jawaban yang dianggap benar

Adapun hipotesa yang penulis kemukakan adalah sebagai berikut :

1. Diduga dengan menggunakan saluran komunikasi horizontal, menimbulkan semangat kerja karyawan di Perusahaan Jamu Parang Husada Kediri.

2. Diduga dengan menggunakan saluran komunikasi vertikal, menimbulkan semangat kerja karyawan di Perusahaan Jamu Parang Husada Kediri.

3. Diduga dengan menggunakan saluran komunikasi diagonal, menimbulkan semangat kerja karyawan di Perusahaan Jamu Parang Husada Kediri.

4. Diduga dengan mengetahui pengaruh komunikasi horizontal, komunikasi vertikal, dan komunikasi diagonal berpengaruh secara bersama-sama terhadap semangat kerja karyawan di Perusahaan Jamu Parang Husada Kediri.

\section{METODE PENELITIAN}

\section{A. Populasi dan Sampel}

a. Populasi dalam penelitian ini adalah seluruh karyawan di Perusahaan Jamu Parang Husada Kediri yang semuanya sebanyak 102 orang

b. Populasi tersebut tidak seluruhnya diteliti, tetapi diambil sebagian saja sebagai sampel dengan menggunakan rumus Yamane (Rachmat, 1985) sebagai berikut

$$
\mathrm{n}=\frac{\mathrm{N}}{\mathrm{N}(\mathrm{d})^{2}+1}
$$

Keterangan:

$\mathrm{n}=$ ukuran sampel $\mathrm{N}$

$=$ ukuran populasi

$\mathrm{d}=$ presisi yang digunakan $10 \%$

Penulis mengambil Populasi dalam penelitian ini adalah 102 orang dan dihitung dengan rumus tersebut menjadi sebagai berikut :

$$
\frac{102}{102(0,1)^{2}+1}=50,495 \approx 50 \text { orang }
$$

Untuk mempermudah analisa maka jumlah sampel yang diambil sebagai responden sebanyak 50 orang. 


\section{B. Teknik Pengambilan Sampel}

secara proporsional pada tiap-tiap sub bagian/unit kerja di Perusahaan Jamu Parang Husada Kediri., dimana setiap anggota populasi mempunyai kesempatan yang sama untuk dipilih sebagai sampel.

\section{Penentuan Jumlah Sampel}

Untuk menentukan jumlah sampelnya penulis menggunakan teknik probability sampling, yaitu teknik sampling yang memberikan peluang sama bagi setiap unsur (anggota) untuk dipilih menjadi anggota sampel. Penulis menggunakan sample random sampling sebagai dasar pengambilan sampel. Sample random sampling adalah sebuah sampel yang diambil sedemikian rupa sehingga setiap unit penelitian atas penelitian berpeluang sama untuk dipilih sebagai sampel.

Perhitungan jumlah sampel dari masing-masing bagian dapat dilihat sebagai berikut

\section{Tabel 1}

Jumlah Sampel dari per Bagian

di Perusahaan Jamu Parang Husada Kediri

\begin{tabular}{|l|l|c|c|}
\hline No. & \multicolumn{1}{|c|}{ Bagian } & Populasi & Sampel Penelitian \\
\hline 1. & Bagian Produksi & 18 & 8 \\
\hline 2. & Bagian Pembelian & 7 & 3 \\
\hline 3. & Administrasi\& Keuangan & 7 & 3 \\
\hline 4. & Bagian Personalia & 7 & 8 \\
\hline 5. & Bagian Simplisia & 16 & 6 \\
\hline 6. & Bagian Pengemasan & 12 & 4 \\
\hline 7. & Bagian Penggorengan & 10 & 9 \\
\hline 8. & Bagian Pemasaran & 15 & 50 \\
\hline 9. & Bagian unit obat $1 / 2$ jadi & 10 & 5 \\
\hline Total & & 102 & \\
\hline
\end{tabular}

Sumber: Data diolah, 2014

\section{Data dan Teknik Pengumpulannya}

\section{Jenis Data}

a. Data Primer

Adalah data yang pertama kali diambil langsung dari sumbernya, dimana peneliti telah menyebarkan kuiserner kepada karyawan. Yang termasuk dalam data ini adalah data yang berkaitan dengan kondisi komunikasi kerja, semangat kerja, dan hubungan diantaranya menurut persepsi Karyawan.

b. Data Sekunder

Adalah data yang diperoleh dalam bentuk sudah jadi dan pengolahannya sudah dilakukan oleh pihak lain sehingga peneliti tinggal memanfaatkannya. Yang termasuk data sekunder dalam penelitian ini adalah data umum instansi seperti struktur organisasi, sejarah singkat instansi dan jumlah Karyawan 


\section{Teknik Pengumpulan Data}

a. Dokumentasi

Dalam metode dokumentasi ini, peneliti mengambil data yang telah tersedia dari Perusahaan yang berkaitan dengan gambaran umum Perusahaan seperti sejarah singkat instansi, struktur organisasi, dan jumlah karyawan yang ada.

b. Kuesioner

Pada metode kuesioner ini, adalah suatu cara pengumpulan data dengan memberikan daftar pertanyaan tertulis untuk Karyawan. Terdapat dua jenis pertanyaan yang diajukan kepada responden, yaitu pertanyaan tertutup dan pertanyaan terbuka.

c. Wawancara

Yaitu metode mengumpulkan informasi dengan mengajukan pertanyaan-pertanyaan secara lisan, interview atau wawancara digunakan oleh peneliti untuk menilai keadaan seseorang atau kepada pihak perusahaan

d. Observasi

Seringkali orang mengartikan observasi sebagai suatu aktiva yang sempit, yakni memperhatikan sesuatu dengan menggunakan mata. Di dalam pengertian psikologi, observasi atau yang disebut pula dengan pengamatan, meliputi kegiatan pemuatan perhatian terhadap sesuatu objek dengan menggunakan seluruh alat indra. Di dalam penelitian observasi dapat dilakukan dengan tes, kuesioner, rekaman gambar, rekaman suara.

Komunikasi horizontal, komunikasi vertikal, dan komunikasi diagonal dengan dua cara, yaitu:

a. Observasi non-sistematis, yang dilakukan oleh pengamat dengan tidak menggunakan instrumen pengamatan.

b. Observasi sistematis, yang dilakukan oleh pengamat dengan menggunakan pedoman sebagai instrumen pengamatan.

\section{E. Identifikasi Variabel} terdiri dari :

Penulis mengggunakan dua variabel yang digunakan dalam penelitian ini , yang

\section{a. Variabel Bebas ( Variabel Independent)}

adalah variabel yang mempengaruhi variabel terikat (Variabel dependent). Dalam penelitian ini terdapat 3 variabel independent, yaitu :

1. Komunikasi vertikal (disimbolkan $\mathrm{X}_{1}$ )

2. Komunikasi horisontal (disimbolkan $\mathrm{X}_{2}$ )

3. Komunikasi diagonal (disimbolkan $\mathrm{X}_{3}$ )

b. Variabel Terikat (Variabel dependent)

Adalah variabel yang dipengaruhi oleh variabel independent. Variabel dependent dalam penelitian ini adalah semangat kerja (disimbolkan Y). 


\section{F. Definisi Operasional Variabel}

\section{a. Variabel Bebas (Variabel Independent)}

Variabel independent merupakan variabel yang hubungannya dengan variabel lain bertindak sebagai penyebab atau yang mempengaruhi variabel lain. Yang termasuk variabel independent antara lain :

1. Variabel komunikasi vertikal (X )

Komunikasi vertikal adalah komunikasi yang terjadi antara atasan dan bawahan, dapat dibagi menjadi dua yaitu :

a. Komunikasi ke bawah

Komunikasi ke bawah digunakan untuk memberikan informasi, mengarahkan, mengkoordinasikan dan menilai orang-orang bawahan.

b. Komunikasi ke atas

Komunikasi ke atas adalah laporan-laporan yang disampaikan ke atas dalam hirarki teoritas untuk memberikan informasi kepada manajemen yang lebih tinggi mengenai kemajuan sasaran-sasaran dan masalah-masalah sekarang.

Data untuk pengukuran variabel ini menggunakan skala 1-5, dimulai dengan sangat tidak setuju sampai dengan sangat setuju.Skala ini menyatakan jumlah quistioner yang disebar ke responden untuk mendapatkan jawaban atas pertanyaan tersebut.

2. Variabel komunikasi horisontal (X )

Komunikasi horisontal sering digunakan untuk menyatakan pertukaran-pertukaran di antara unit-unit organisasi pada perusahaan.Data untuk pengukuran variabel ini menggunakan skala 1-5, dimulai dengan sangat tidak setuju sampai dengan sangat setuju. Skala ini menyatakan jumlah quistioner yang disebar ke responden untuk mendapatkan jawaban atas pertanyaan tersebut.

3. Variabel komunikasi diagonal (X )

Komunikasi diagonal ini menunjukkan hubungan departemen di mana sistem ini mengandung ketergantungan antar departemen. Data untuk pengukuran variabel ini menggunakan skala 1-5, dimulai dengan sangat tidak setuju sampai dengan sangat setuju. Skala ini menyatakan jumlah quistioner yang disebar ke responden untuk mendapatkan jawaban atas pertanyaan tersebut.

\section{b. Variabel Terikat (Variabel dependent)}

Variabel dependent merupakan variabel yang tergantung pada variabel lain atau variabel yang dapat dipengaruhi oleh variabel lain. Yang termasuk variabel dependent yaitu : semangat kerja (Y).

Semangat kerja adalah keinginan untuk bekerjasama dari sekelompok manusia melalui disiplin bersama untuk mencapai tujuan yang diinginkan.Data untuk pengukuran variabel ini menggunakan skala 1-5, dimulai dengan sangat tidak setuju sampai dengan sangat setuju.Skala ini menyatakan jumlah quesioner yang disebar ke responden untuk mendapatkan jawaban atas pertanyaan tersebut. 


\section{G. Teknik Analisis Data}

\section{a. Korelasi Berganda}

Korelasi berganda merupakan alat ukur untuk mengetahui pertautan antara variabel tidak bebas ( variabel Y) dengan beberapa variabel bebas (variabel X, X , X ) secara serempak.

\section{b. Regresi Linier Berganda}

Untuk mengetahui seberapa besar variabel-variabel bebas tersebut berpengaruh terhadap variabel tergantung, maka digunakan teknik regresi linier berganda dengan harapan dapat diketahui faktor yang paling dominan dan berpengaruh.

Selanjutnya dalam analisis data tersebut, penulis menggunakan perhitungan Korelasi berganda dan Regresi Linier Berganda. Kemudian dengan pertimbangan efisiensi dan efektivitas, maka dalam perhitungannya penulis menggunakan pengolahan data dengan Program Computer, Software SPSS ( Statistic Program Social Scince ) versi 16.00.

\section{HASIL PENELITIAN DAN PEMBAHASAN}

Hasil analisis regresi antara variabel komunikasi vertikal, komunikasi horisontal, dan komunikasi diagonal terhadap semangat kerja pegawai dengan menggunakan program SPSS dapat disajikan secara ringkas pada tabel berikut :

Tabel 2

Rekapitulasi Hasil Analisis Regresi Linier Berganda

\begin{tabular}{|l|l|l|l|c|}
\hline \multicolumn{1}{|c|}{ Variabel } & $\begin{array}{c}\text { Koefisien } \\
\text { Regresi }\end{array}$ & T hitung & Prob. & $\mathbf{r}^{2}$ \\
\hline Kom. Vertikal $\left(\mathrm{X}_{1}\right)$ & 0,263 & 2,201 & 0,033 & 0,845 \\
Kom. Horisontal $\left(\mathrm{X}_{2}\right)$ & 0,242 & 2,034 & 0,043 & 0,861 \\
Kom. Diagonal $\left(\mathrm{X}_{3}\right)^{2}$ & 0,358 & 3,284 & 0,002 & 0,874 \\
\hline Konstanta & 6,860 & & & \\
\hline $\mathrm{R}=0,906$ & & \\
$\mathrm{R}^{2}=0,821$ & $\mathrm{~F}=70,311$ \\
Prob $=0,000$ & \\
\hline & $\mathrm{F}_{\text {Tabel }}=2,61$ \\
$\mathrm{~T}_{\text {Tabel }}=2,021$ & \\
\hline Persamaan Regresi : \\
$\mathrm{Y}=6,860+0,263 \mathrm{X}_{1}+0,242 \mathrm{X}_{2}+0,358 \mathrm{X}_{3}$ \\
Sumber : Data Primer Diolah
\end{tabular}

Konstanta sebesar 6,860 menunjukkan tingkat semangat kerja karyawan, jika karyawan tidak mempertimbangkan faktor komunikasi vertikal, komunikasi horisontal dan komunikasi diagonal.

Koefisien regresi variabel ukomunikasi vertikal sebesar 0,263 menunjukkan bahwa apabila variabel komunikasi vertikal berubah naik/turun 1 satuan, maka semangat kerja pegawai akan berubah naik/turun sebesar 0,263 satuan dengan syarat yang sama, artinya 
semakin baik komunikasi.

Koefisien regresi komunikasi horisontal sebesar 0,242 menunjukkan besarnya pengaruh variabel komunikasi horisontal terhadap semangat kerja karyawan dengan pengaruh yang searah, artinya semakin baik komunikasi karyawan per bagian maka semakin besar semangat karyawan Perusahaan Jamu Parang Husada Kediri dengan menganggap variable lain tetap.

Koefisien regresi komunikasi diagonal sebesar 0,358 menunjukkan besarnya pengaruh variabel komunikasi diagonal terhadap semangat kerja karyawan Perusahaan Jamu Parang Husada Kediri dengan pengaruh searah, artinya semakin baik komunikasi karyawan antar bagian maka semakin besar semangat kerja karyawan, dengan menganggap variabel lain tetap.

Koefisien korelasi berganda (R) sebesar 0,906 (mendekati 1) menunjukkan adanya hubungan yang sangat kuat dan searah antara variabel komunikasi vertikal, komunikasi horisontal dan komunikasi diagonal dengan semangat kerja karyawan Perusahaan Jamu Parang Husada Kediri.

\section{Uji F}

Uji f digunakan untuk menguji keberartian pengaruh secara keseluruhan variabel secara keseluruhan variabel komunikasi vertikal, komunikasi horisontal dan komunikasi diagonal dengan semangat kerja karyawan Perusahaan Jamu Parang Husada Kediri.

Hasil analisis diperoleh nilai $F_{\text {hitung }}$ sebesar 70,311 dengan nilai probabilitas Koefisien determinasi berganda $\left(\mathrm{R}^{2}\right)$ sebesar 0,821 menunjukkan bahwa variabel komunikasi vertikal, komunikasi horisontal dan komunikasi diagonal memberikan kontribusi sebesar 82,1\% terhadapsemangat kerja karyawan Perusahaan Jamu Parang Husada Kediri, sebesar 17,9\% disebabkan oleh variabel lain yang tidak diteliti

\section{Uji t}

Adalah pengujian signifikansi pengaruh secara parsial terhadap semangat kerja karyawan Perusahaan Jamu Parang Husada Kediri dilakukan dengan uji t.

a. Komunikasi Vertikal (X)

Hasil analisis diperoleh nilai $\mathrm{t}=2,201$ dengan probabilitas 0,033 lebih kecil 0,05 sehingga teruji bahwa variabel komunikasi vertikal berpengaruh signifikan terhadap semangat kerja karyawan Perusahaan Jamu Parang Husada Kediri.

Koefisien determinasi parsial $\left(\mathrm{r}^{2}\right)$ sebesar 0,845 memiliki arti sebesar 84,5\% semangat kerja pegawai ditentukan oleh variabel komunikasi vertical 
b. Komunikasi Horisontal (X) Hasil analisis diperoleh nilai $\mathrm{T}_{\text {hitung }}=2,034$ dengan probabilitas 0,043 lebih kecil 0,05

sehingga teruji bahwa variabel komunikasi horisontal berpengaruh signifikan terhadap semangat kerja karyawan Perusahaan Jamu Parang Husada Kediri .

Koefisien determinasi parsial $\left(\mathrm{r}^{2}\right)$ sebesar 0,861 memiliki arti sebesar86,1\% semangat kerja pegawai dipengaruhi oleh variabel komunikasi horisontal.

c. Komunikasi Diagonal $\left(\mathrm{X}_{3}\right)$

analisis diperoleh nilai $t_{\text {hitung }}=3,284$ dengan probabilitas 0,002 lebih kecil 0,05 sehingga teruji bahwa variabel komunikasi diagonal berpengaruh signifikan terhadapsemangat kerja karyawan Perusahaan Jamu Parang Husada Kediri.

Koefisien determinasi parsial $\left(\mathrm{r}^{2}\right)$ sebesar 0,874 memiliki arti sebesar 87,4\% semangat kerja pegawai dipengaruhi oleh variabel komunikasi diagonal.

Hasil uji t di atas dapat diketahui bahwa secara parsial masing-masing variabel berpengaruh signifikan terhadap semangat kerja karyawan Perusahaan Jamu Parang Husada Kediri.

Selanjutnya untuk menentukan variabel yang berpengaruh dominan dapat dilihat dari koefisien regresi dan koefisien korelasi paling besar dan paling signifikan, ternyata variabel komunikasi diagonal merupakan variabel yang memiliki koefisien regresi paling besar $(0,358)$ dan paling signifikan (probabilitas $=0,002$ ), koefisien korelasi sebesar 0,440 atau koefisien determinasi 0,874 . Jadi dari ketiga variabel komunikasi dalam penelitian ini komunikasi diagonal merupakan variabel dominan yang mempengaruhi terhadap semangat kerja karyawan Perusahaan Jamu Parang Husada Kediri

Hal karena lingkungan kerja sangat mendukung kondisi ini terjadi komunikasi diagonal tersebut, nampak dalam pengamatan peneliti di lapangan bahwa antara atasan dan bawahan dari berbagai bagian yang berbeda diperusahaan Jamu Parang Husada Kediri, komunikasi mereka terjalin baik, begitu juga antara karyawan yang berbeda bagian pekerjaan juga terjalin dengan baik.

Pada diskripsi variabel komunikasi diagonal, yang memperkuat adalah adanya keuntungan yang diperoleh dalam hal peningkatan kualitas hasil kerja mereka, karena dengan hubungan komunikasi yang terjalin baik walaupun mereka berbeda bagian, informasi yang diperlukan bagi mereka dari perusahaan cepat tersampaikan, sehingga kerjasama diantara karyawan juga menjadi factor yang sangat mempengaruhi semangat kerja mereka. Selain itu komunikasi semua karyawan perusahaan ini diluar pekerjaan juga terjalin baik, dikarenakan kebanyakan mereka hidup bertetangga satu desa .

\section{KESIMPULAN DAN SARAN}

\section{A. Kesimpulan}

Berdasarkan uraian yang telah dikemukakan dari Bab I sampai dengan Bab IV dan berdasarkan permasalahan yang penulis ajukan, maka dapat diambil beberapa kesimpulan sebagai berikut : 
1. Hasil pengujian dengan menggunakan saluran komunikasi horizontal (X ) diketahui 2,034 yang menimbulkan semangat kerja karyawan di Perusahaan Jamu Parang Husada Kediri.

2. Hasil pengujian dengan menggunakan saluran komunikasi vertikal (X) diketahui 2,201 yang menimbulkan semangat kerja karyawan di Perusahaan Jamu Parang Husada Kediri.

3. Hasil pengujian dengan menggunakan saluran komunikasi Diagonal (X) diketahui 3,284 yang menimbulkan semangat kerja karyawan di Perusahaan Jamu Parang Husada Kediri.

4. Pengujian yang mengunakan statistik maka dapat dilihat nilai koefisien korelasisebesar 0,906. Dan hasilpengujian dengan regresi berganda diketahui persamaan regresi hubungan antara variabel budaya organisasi, sosial, pribadi dan psikologis maka komunikasi diagonal mempunyai pengaruh yang paling dominan yaitu dengan koefisien regresi sebesar 0,358. Halini disebabkan karena, para karyawan merasa bahwa dengan komunikasi yang lintas bagian tersebut atau diagonal mereka bisa dengan bebas bertukar informasi saling membantu dalam hal pekerjaan atau masalah- masalah lain diantara kawan-kawan satu perusahaan. Sehingga semangat mereka bertambah dengan komunikasi yang terjalin dengan baik tersebut.

\section{B. Saran}

Adapun saran-saran yang dapat penulis sampaikan adalah sebagai berikut :

1. Hendaknya Pimpinan Perusahaan Jamu Parang Husada Kediri.mendukung sepenuhnya komunikasi antar pegawai baik itu secara vertikal, horisontal maupun diagonal. Karena kenyamanan dan lingkungan organisasi yang didukung oleh komunikasi yang terjalin baik diantara semua karyawan perusahaan akan semakin kuat semangat mereka untuk bekerja.

2. Untuk menciptakan kondisi kerja yang baik, akan lebih baik jika pimpinan melakukan pertemuan secara rutin dengan Karyawan. Hal ini untuk mendengar secara langsung keluhan maupun saran dari karyawan yang menyangkut kerja mereka.

3. Untuk menambah semangat para karyawan perusahaan disarankan memberikan stimulasi berupa bonus bagi karyawan yang mempunyai prestasi kerja yang baik.

4. Komunikasi lintas bagian atau diagonal menjadi yang paling dominan di perusahaan ini, sehingga perusahaan disaran memfasilitasinya dengan programprogram yang lebih bervariasi terutama yang berkaitan dengan komunikasi diagonal ini. 


\section{DAFTAR PUSTAKA}

A.W. Wijaya. 2004. Komunikasi-komunikasi dan Hubungan Masyarakat. Penerbit PT. Bina Aksara. Jakarta

Alex S. Nitisemito. 2005. Manajemen Personalia. Cetakan Keempat. Penerbit Ghalia Indonesia. Jakarta

Pengantar Metode Statistika. Jakarta : LP3ES

Edwin B. Flippo. 25 Agustus 2008. Principle of Personal Management. FiveEdition. Mc Graw Hill Inc

Heidjrachman Ranupandojo dan Suad Husnan.2005. Manajemen Personalia. Penerbit Ghalia Indonesia, Jakarta

James G. Robbins dan Barbara S. Jones.2004. Effective Communication for Today's Manager. Terjemahan oleh Turman Sirait, Penerbit CV. Tulus Jaya, Jakarta

Muchdarsyah Sinungan. 2005. Produktivitas. Edisi Kedua. Penerbit Bumi Aksara, Jakarta

Phil Astrid S. Susanto. 2005. Komunikasi Dalam Teori dan Praktek. Penerbit Bina Citra, Jakarta

Winarno Surachmad. 2005. Pengantar Metode Ilmiah. Edisi Keenam. Penerbit Tarsito, Bandung

Zaenal Mustofa EQ. 2010. Pengantar Mikrostat. Penerbit Ghalia Indonesia, Jakarta 